\title{
The Alphabet of the Elementary Microbiology: Revisited
}

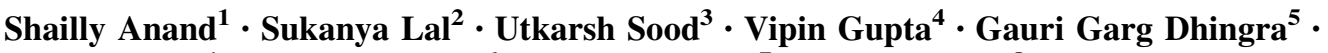 \\ Renu Solanki ${ }^{1} \cdot$ Jasvinder Kaur $^{6} \cdot$ Roshan Kumar $^{7} \cdot$ Anjali Saxena $^{8}$. \\ Ankita Dua ${ }^{9}$. Charu Tripathi ${ }^{10}$. Chandni Talwar ${ }^{11}$ - Charu Dogra Rawat ${ }^{2}$. \\ Harpreet Kaur ${ }^{11}$ - Helianthous Verma ${ }^{2} \cdot$ Jaspreet Kaur $^{12}$ - Mansi Verma ${ }^{13}$. \\ Mona Singh $^{14} \cdot$ Princy Hira $^{12}$ - Nirjara Singhvi ${ }^{15}$ - Nitish Kumar Mahato ${ }^{1}$. \\ Om Prakash ${ }^{16} \cdot$ Jaya Malhotra $^{17} \cdot$ Rup Lal $^{3} \cdot$ Vipin Chandra Kalia ${ }^{18}$
}

Published online: 6 October 2021

(C) Association of Microbiologists of India 2021

Organizations across the Globe support The Right to Education programs [1,2]. The best stage to start learning is childhood. Child populations in the age groups $0-4$ and 5-11 constitute around $46 \%$ of the children under 18 [3]. Approximately 1 billion children attend school on any given day around the world [2]. The urge to learn is a slow process. However, the scenario seems to have changed dramatically since the beginning of the Covid pandemic. The desire to learn has never been greater than that

Rup Lal

ruplal@gmail.com

$\triangle$ Vipin Chandra Kalia

vckaliaku@gmail.com

1 Department of Zoology, Deen Dayal Upadhyaya College (University of Delhi), Dwarka, New Delhi 110 078, India

2 Department of Zoology, Ramjas College (University of Delhi), Delhi 110 007, India

3 The Energy \& Resources Institute (TERI), New Delhi 110 003, India

4 Ministry of Environment, Forest and Climate Change, Govt. of India, New Delhi 110 003, India

5 Department of Zoology, Kirori Mal College (University of Delhi), Delhi 110 007, India

6 Department of Zoology, Gargi College (University of Delhi), New Delhi 110 049, India

7 Post-Graduate Department of Zoology, Magadh University, Bodh Gaya, Bihar 824 234, India

8 Department of Zoology, Bhaskaracharya College of Applied Sciences (University of Delhi), Dwarka, New Delhi 110 075, India

9 Department of Zoology, Shivaji College (University of Delhi), Raja Garden, New Delhi 110 027, India recorded in the case of Corona. Scientists, medical practitioners, and officials of WHO, Governments, Health Departments have been responding rapidly to learn more and advise the public. There has been a global agreement to share information on Covid-19 and "Whoever finds the Vaccine must share it" [4]. It may not be an over-exaggeration to state all school kids have learned that $\mathrm{C}$ stands for Corona. Teaching Microbiology and Biotechnology in schools and colleges has been initiated [5]. Keeping in

10 Department of Zoology, CMP College, University of Allahabad, Prayagraj, Uttar Pradesh 211 002, India

11 Department of Zoology, University of Delhi, University Enclave, Delhi 110 007, India

12 Department of Zoology, Maitreyi College (University of Delhi), Bapudham Complex, Chanakyapuri, New Delhi 110 021, India

13 Department of Zoology, Sri Venkateswara College (University of Delhi), Dhaula Kuan, New Delhi 110 021, India

14 Special Centre for Molecular Medicine, Jawaharlal Nehru University, New Delhi 110 067, India

15 PhiXgen Pvt. Ltd, Gurugram, Haryana 122 001, India

16 National Centre for Microbial Resource (NCMR), National Centre for Cell Science (NCCS), Pune, Maharashtra 411 007, India

17 Department of Zoology, Hansraj College (University of Delhi), Delhi 110 007, India

18 Department of Chemical Engineering, Konkuk University, 1 Hwayang-Dong, Gwangjin-Gu, Seoul 05029, Republic of Korea 
view the need to teach Microbiology at the School and College levels, we propose the Alphabet of The Elementary Microbiology (Table 1).

Despite 3.8 billion years since the origin of life and the ubiquitous nature of microbes, the general perception of the population towards the pervasive impact of this microbial diversity remains blurred. The role of microbes in the sustenance of the biosphere is well known. The time is ripe to popularize these among the population at large. The education system at the elementary school level is the best entry point for disseminating this information and the underlying concepts. Igniting young minds with this magical world of microbes can go a long way in generating awareness among society. Figure 1 provides a glimpse of the diversity of microbial landscape for promoting Microbial Literacy among children. And a detailed description

Table 1 The alphabet of the elementary microbiology

\begin{tabular}{|c|c|c|c|c|}
\hline \multirow[t]{2}{*}{ Alphabet } & \multicolumn{3}{|l|}{ Microbe } & \multirow[t]{2}{*}{ Reference } \\
\hline & Scientific name & $\begin{array}{l}\text { Taxonomic } \\
\text { category }\end{array}$ & Applications & \\
\hline A & Amycolatopsis & Actinobacteria & Antibiotic and anti-inflammatory agent & {$[6]$} \\
\hline B & Bacillus & Firmicutes & Biofuel, Biopolymers & {$[7,8]$} \\
\hline $\mathrm{C}$ & Corona & Virus & Severe acute respiratory syndrome coronavirus (SARS-CoV-2) & {$[9,10]$} \\
\hline $\mathrm{D}$ & Deinococcus & $\begin{array}{l}\text { Deinococcus- } \\
\text { Thermus }\end{array}$ & Highly resistant to X-rays & [11] \\
\hline $\mathrm{E}$ & Enterobacter & $\begin{array}{l}\gamma- \\
\text { proteobacteria }\end{array}$ & Biofuel, Infectious diseases & [11] \\
\hline $\mathrm{F}$ & Flavobacterium & Bacteroidetes & Spoilage of food products & [11] \\
\hline G & Geobacillus & Firmicutes & $\begin{array}{l}\text { Enzymes for White biotechnology: lipases, pullulanase, } \alpha \text {-and } \beta \text {-glucosidase, } \\
\text { glycoside hydrolase }\end{array}$ & {$[12]$} \\
\hline $\mathrm{H}$ & Helicobacter & ${ }^{\varepsilon-}$ proteobacteria & Pathogen to human beings & [13] \\
\hline I & Idiomarina & $\begin{array}{l}\gamma- \\
\text { proteobacteria }\end{array}$ & Exopolysaccharide for improving texture of food & [11] \\
\hline $\mathrm{J}$ & Janibacter & Firmicutes & Human infections & {$[11]$} \\
\hline K & Kocuria & Actinobacteria & Ability to grow in Mars-like conditions & {$[11]$} \\
\hline $\mathrm{L}$ & Lactobacillus & Firmicutes & Probiotics, health promoter & [14] \\
\hline M & Mycobacterium & Actinobacteria & Pathogen causing tuberculosis & {$[15]$} \\
\hline $\mathrm{N}$ & Nocardia & Actinobacteria & Bioactive molecule: Immunosuppresive, antibacterial & [16] \\
\hline $\mathrm{O}$ & Oceanibaculum & $\begin{array}{l}\alpha- \\
\text { proteobacteria }\end{array}$ & Persistent organic matter degrader & {$[11]$} \\
\hline $\mathrm{P}$ & Pseudomonas & $\begin{array}{l}\gamma- \\
\text { proteobacteria }\end{array}$ & Infects plants and animals, plant growth promoter & {$[17]$} \\
\hline $\mathrm{R}$ & Paenibacillus & Firmicutes & $\begin{array}{l}\text { Produces 2,3-butanediol, exopolysaccharides, cytokinin, antibiotics, fixes nitrogen, } \\
\text { plant growth promoter, solubilizes phosphorus in soil }\end{array}$ & [18] \\
\hline S & Streptococcus & Firmicutes & Throat and blood infections & [19] \\
\hline $\mathrm{T}$ & Thermus & $\begin{array}{l}\text { Deinococcus- } \\
\text { Thermus }\end{array}$ & Diverse molecular biology techniques & {$[20]$} \\
\hline $\mathrm{U}$ & Ureaplasma & Tenericutes & Causes urethritis and infect chorionic villi tissues & {$[21]$} \\
\hline $\mathrm{V}$ & Vibrio & $\begin{array}{l}\gamma- \\
\text { proteobacteria }\end{array}$ & Pathogen causing cholera & {$[22]$} \\
\hline W & Winogradskyella & Bacteroidetes & Insights into the role of proteorhodopsin-mediated phototrophy & {$[11]$} \\
\hline $\mathrm{X}$ & Xanthomarina & Bacteroidetes & $\beta$-Galactosidase activity & {$[11]$} \\
\hline Y & Yersinia & $\begin{array}{l}\gamma- \\
\text { proteobacteria }\end{array}$ & Pathogen contaminating water, food, and blood transfusions & [23] \\
\hline $\mathrm{Z}$ & Zooshikella & $\begin{array}{l}\gamma- \\
\text { proteobacteria }\end{array}$ & Production of pigments: Prodigiosin and cycloprodigiosin & [11] \\
\hline
\end{tabular}

Q: Names of bacteria or fungi initializing with $\mathrm{Q}$ could not be traced in the literature available in the public domain 


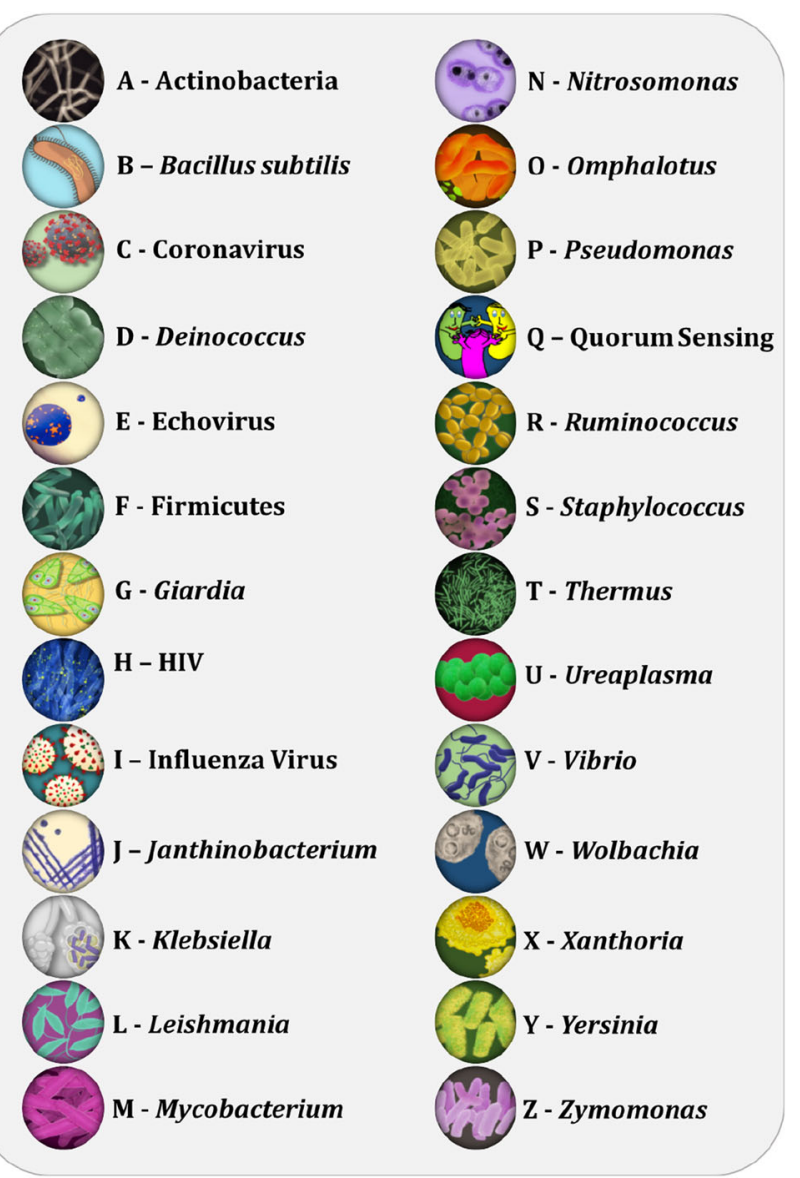

Fig. 1 The Alphabet of Microbiology for the Grown-ups

has been given as supplementary material: A Glimpse into the Magical World of Microorganisms (Figure S1). This initiative is the beginning of a New Era for reinforcing the alphabet of microbiology in society and ignite awareness for a sustainable future.

Supplementary Information The online version contains supplementary material available at https://doi.org/10.1007/s12088-02100987-7.

\section{References}

1. http://righttoeducation.in/know-your-rte/about Accessed from 23 Aug 2021

2. https://www.unicef.org/education Accessed from 23 Aug 2021

3. https://datacenter.kidscount.org/data/tables/101-child-populationby-age-group\#detailed Accessed from 23 Aug 2021

4. https://www.hrw.org/report/2020/10/29/whoever-finds-vaccinemust-share-it/strengthening-human-rights-and-transparency Accessed from 23 Aug 2021

5. Lal R (2010) Microbiology and biotechnology education in India. Indian J Microbiol 50:251-252. https://doi.org/10.1007/s12088010-0064-3

6. Singhvi N, Gupta V, Singh P et al (2020) Prediction of transcription factors and their involvement in regulating rifamycin production in Amycolatopsis mediterranei S699. Indian J
Microbiol 60:310-317. https://doi.org/10.1007/s12088-02000868-5

7. Kumar P, Singh M, Mehariya S, Patel SKS, Lee JK, Kalia VC (2014) Ecobiotechnological approach for exploiting the abilities of Bacillus to produce co-polymer of polyhydroxyalkanoate. Indian J Microbiol 54:151-157. https://doi.org/10.1007/s12088014-0457-9

8. Kumar P, Mehariya S, Ray S, Mishra A, Kalia VC (2015) Biodiesel industry waste: a potential source of bioenergy and biopolymers. Indian J Microbiol 55:1-7. https://doi.org/10.1007/ s12088-014-0509-1

9. Patel SK, Lee JK, Kalia VC (2020) Deploying biomolecules as anti-COVID-19 agents. Indian J Microbiol 60:263-268. https:// doi.org/10.1007/s12088-020-00893-4

10. Rishi P, Thakur K, Vij S, Rishi L, Singh A, Kaur IP, Patel SKS, Lee J-K, Kalia VC (2020) Diet, gut microbiota and COVID-19. Indian J Microbiol 60:420-429. https://doi.org/10.1007/s12088020-00908-0

11. Hira P, Singh P, Pinnaka AK et al (2020) Taxonomically characterized and validated bacterial species based on $16 \mathrm{~S}$ rRNA gene sequences from India during the last decade. Indian $\mathbf{J}$ Microbiol 60:54-61. https://doi.org/10.1007/s12088-019-00845-7

12. Singh DN, Sood U, Singh AK, Gupta V, Shakarad M, Rawat CD, Lal R (2019) Genome sequencing revealed the biotechnological potential of an obligate thermophile Geobacillus thermoleovorans strain RL isolated from hot water spring. Indian $\mathrm{J}$ Microbiol 59:351-355. https://doi.org/10.1007/s12088-019-00809-x

13. Puri A, Rai A, Dhanaraj PS, Lal R, Patel DD, Kaicker A, Verma M (2016) An in silico approach for identification of the pathogenic species, Helicobacter pylori and its relatives. Indian J Microbiol 56:277-286. https://doi.org/10.1007/s12088-016-05757

14. Koul S, Kalia VC (2016) Comparative genomics reveals biomarkers to identify Lactobacillus species. Indian J Microbiol 56:253-263. https://doi.org/10.1007/s12088-016-0605-5

15. Sood U, Bajaj A, Kumar R, Khurana S, Kalia VC (2018) Infection and microbiome: impact of tuberculosis on human gut microbiome of Indian cohort. Indian J Microbiol 58:123-125. https://doi.org/10.1007/s12088-018-0706-4

16. Solanki R, Khanna M, Lal R (2008) Bioactive compounds from marine actinomycetes. Indian J Microbiol 48:410-431. https:// doi.org/10.1007/s12088-008-0052-Z

17. Bhushan A, Joshi J, Shankar P, Kushwah J, Raju SC, Purohit HJ, Kalia VC (2013) Development of genomic tools for the identification of certain Pseudomonas up to species level. Indian J Microbiol 53:253-263. https://doi.org/10.1007/s12088-013-04121

18. Lal S, Tabacchioni S (2009) Ecology and biotechnological potential of Paenibacillus polymyxa: a minireview. Indian $\mathrm{J}$ Microbiol 49:2-10. https://doi.org/10.1007/s12088-009-0008-y

19. Kalia VC, Kumar R, Kumar P, Koul S (2016) A genome-wide profiling strategy as an aid for searching unique identification biomarkers for Streptococcus. Indian J Microbiol 56:46-58. https://doi.org/10.1007/s12088-015-0561-5

20. Dwivedi V, Kumari K, Gupta SK et al (2015) Thermus parvatiensis $\mathrm{RL}^{\mathrm{T}}$ sp. nov., isolated from a hot water spring, located atop the Himalayan Ranges at Manikaran. India Indian J Microbiol 55:357-365. https://doi.org/10.1007/s12088-015-05384

21. Kokkayil P, Dhawan B (2015) Ureaplasma: Current perspectives. Indian J Med Microbiol 33:205-214. https://doi.org/10.4103/ 0255-0857.154850

22. Kalia VC, Kumar P, Kumar R, Mishra A, Koul S (2015) Genome wide analysis for rapid identification of Vibrio species. Indian $\mathrm{J}$ Microbiol 55:375-383. https://doi.org/10.1007/s12088-015-05535 
23. Kalia VC, Kumar P (2015) Genome wide search for biomarkers to diagnose Yersinia infections. Indian J Microbiol 55:366-374. https://doi.org/10.1007/s12088-015-0552-6
Publisher's Note Springer Nature remains neutral with regard to jurisdictional claims in published maps and institutional affiliations. 